\title{
¿En qué sentido cabe hablar de ética financiera?
}

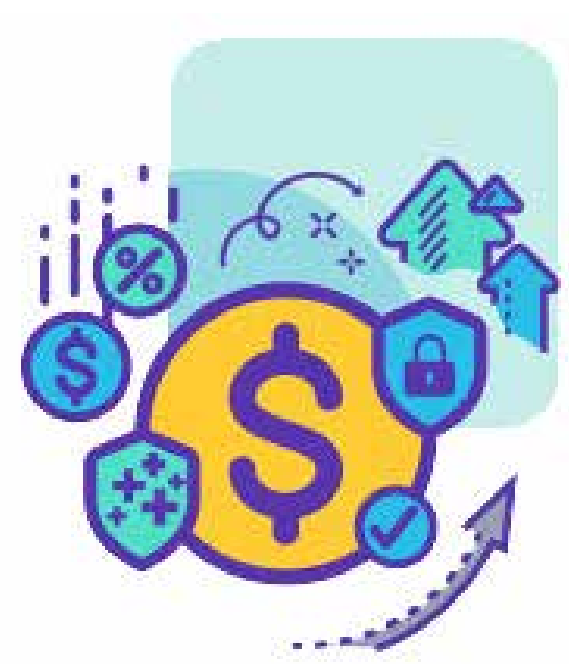

Por. Dr. Ildefonso Camacho S.J.

Doctor en Teología y Licenciado en Filosofía y en Ciencias Sociales.

Ex Presidente de la Fundación Universidad Loyola Andalucía y de la Fundación ETEA.

Fue Director de la Revista «Proyección». Miembro del Consejo de Redacción de la Revista de Fomento Social.

Profesor Emérito de Teología Moral en la Universidad Loyola Andalucía - España

\section{¿Se puede hablar de ética en relación con el mundo financiero?}

Hay situaciones concretas en las que nadie dudaría en responder afirmativamente a esa pregunta. Por ejemplo, cuando hay un comportamiento individual que va en contra de una elemental honestidad, y eso produce efectos negativos para terceros o ganancias escandalosas. A veces, son actuaciones que los medios de comunicación se encargan de difundir, por las consecuencias que se siguen. Es probable, incluso, que sean comportamientos delictivos: están prohibidos por la ley y, por tanto, conllevan un castigo para el que actúa así.

Pero no podemos equiparar precipitadamente lo que está prohibido por la ley y lo que éticamente resulta inaceptable. La ética suele ser más estricta y exigente que la ley. $Y$ existen individuos que tienen una gran habilidad para sortear las prohibiciones legales con actitudes ante las que una persona con una mediana sensibilidad humana se siente incómoda: son casos, por ejemplo, en que se aprovecha una situación de poder para abusar de la debilidad (relativa) de otros.

$Y$ hay más. Porque hasta ahora hemos hablado de comportamientos individuales. Pero la ética no se agota ahí. La ética tiene también una dimensión social que nos permite analizar las estructuras de nuestra sociedad, sus instituciones, y emitir un juicio sobre su coherencia, en función de ciertos valores o de la razón de ser que justifica la existencia de dichas estructuras o instituciones. La ética nos permite tomar distancia crítica sobre la realidad que nos circunda y preguntarnos si responde a unos estándares humanos mínimos, si facilita a los seres humanos que desarrollen sus capacidades y vean realizadas sus aspiraciones 0 , por el contrario, si es un obstáculo para todo ello.
¿Cabe, por ejemplo, hacer una reflexión ética sobre el mercado? Hay quienes niegan esta posibilidad, alegando que el mercado funciona de acuerdo con unas leyes que son las que son y que, en modo alguno, nos está permitido cambiarlas. Pero, ¿se puede decir que todo lo que ocurre en los mercados financieros es bueno para la sociedad? La respuesta a esta pregunta es independiente de que esté en nuestras manos cambiar el funcionamiento de los mercados.

¿Se puede decir que hay que dar por justo el precio que se fija en el mercado mediante el libre juego de la oferta y la demanda? ¿Y si -como acontece muchas veces- ese juego no es tan libre como se pretende? ¿No es posible -y deseable- intervenir en el mercado modificando las condiciones de su funcionamiento o restringiendo la libertad de los que gozan de mayor poder en ellos, con la intención de lograr unos precios más ajustados?

Son muchas preguntas las que surgen. Todas ellas expresan que la reflexión ética no se contenta con contemplar, con una amable resignación, procesos que nos resultan incontrolables. Tampoco se siente cómoda diciendo que son problemas que no está en nuestra mano el resolver, a diferencia de lo que suele ocurrir en la vida personal (donde es más fácil que nuestra vida dependa de decisiones que están a nuestro alcance tomar). Más aun, la reflexión ética no acepta la pretendida neutralidad de la ciencia económica, que profesan quienes creen que el saber científico se limita a analizar lo que ocurre sin pretender actuar sobre ello ni interesarse por los valores y opciones que están detrás. 
Pero cabe todavía dar un paso más en nuestra reflexión ética sobre el mundo de las finanzas. Este desarrollo espectacular de las operaciones financieras, cuyo volumen crece a un ritmo muy superior al de las transacciones de la economía productiva, ¿no merece también una reflexión crítica desde la ética? Porque el mundo de las finanzas nació para lubricar el funcionamiento de la economía real, la que produce los bienes y servicios destinados a satisfacer buena parte de las necesidades de la humanidad: su razón de ser radica en la posibilidad de suministrar recursos económicos a quien temporalmente no dispone de estos y los necesita para emprender una actividad productiva. Dicho de otra manera: la razón de ser de la economía financiera es estar al servicio de la economía real y productiva.

Ahora bien, esta relación de subordinación resulta hoy más que difusa. Las operaciones financieras han alcanzado unas dimensiones cuantitativas muy superiores a las necesidades de la economía real. Dicho con otras palabras: la economía financiera ha alcanzado una notable autonomía respecto a la economía real y ha llegado a encontrar su razón de ser en sí misma. Es como si no necesitara de la economía real y pudiera funcionar, en la hipótesis de que esta ni siquiera existiera.

Alguno se preguntará: ¿y qué problema habría en ello? Pues, por decirlo brevemente, que los términos se habrían invertido; el medio se ha convertido en el fin que orienta toda la actividad. Porque, de estar al servicio de la economía real, la economía financiera se ha convertido en un obstáculo para un sano y equilibrado desarrollo de aquella.

Esta autonomización de la economía financiera no se traduce solo en su crecimiento cuantitativo: también se manifiesta en la sofisticación de sus procedimientos y de los instrumentos ideados no solo para cubrirse de los riesgos, sino para gestionarlos y convertirlos en una ocasión para obtener nuevas y considerables ganancias. Evidentemente, ese mundo complejo que ni los expertos en finanzas llegan a veces a dominar va mucho más allá de lo que exigiría el normal funcionamiento de una economía más atenta a la producción de bienes y servicios.

La misma empresa termina siendo considerada como un patrimonio financiero, cuya rentabilidad se mide, más que por lo que produce y por los excedentes económicos que se siguen de esa producción, por el valor que alcanzan sus acciones en los mercados bursátiles. La práctica retributiva de las stockoptions son un exponente de esta reorientación de la empresa, en la medida en que orienta a sus directivos a poner el centro de sus esfuerzos en incrementar el valor de las acciones.

La crisis financiera que estalló en 2008, y que hoy se mira como un episodio de un pasado psicológicamente cada vez más lejano, nos hizo caer en la cuenta de muchas paradojas y contradicciones. Señalemos al menos estas tres: $1^{\text {a }}$ ) ese desarrollo incontrolado de oscuros instrumentos financieros produjo en los mercados una falta de transparencia que, a la larga, no se podía sostener; $2^{a}$ ) el mercado mostró una vez más que no es capaz, por sí solo, de garantizar un funcionamiento equilibrado de la economía; $3^{a}$ ) una crisis que comenzó siendo financiera acabó arrastrando a toda la economía real, con dramáticos efectos sobre el empleo, la producción y la estabilidad de muchos negocios. ¿Ha quedado todo esto superado y resuelto porque hemos vuelto a unas tasas de crecimiento más aceptables, una vez saneadas con mucho dinero público la mayoría de las instituciones financieras que estuvieron al borde del colapso?

Uno siente una impotencia brutal ante un panorama tan dramático. Es más grave aún si se piensa que se repite lo de siempre: toda crisis económica golpea especialmente a las clases más débiles, que son las más vulnerables. Y no basta decir: ¡Nada podemos hacer! Al menos hay que tomar conciencia de que las cosas no son tan obvias como, tan frecuentemente, se nos quiere hacer creer. Esa toma de conciencia es tarea de la ética, que hace así un innegable servicio a la humanidad.

Y todavía hay una conclusión. No estamos hablando solo de comportamientos individuales, ni solo de prácticas ilegales. La reflexión ética nos lleva a analizar críticamente la realidad, a buscar alternativas, a entrar en un debate público que es propio de las sociedades que quieren ser libres y democráticas. También aquí se aplica aquella fórmula que popularizó Ignacio Ellacuría: "Hacerse cargo de la realidad, cargar con la realidad, encargarse de la realidad". Es una excelente formulación de lo que es nuestro que hacer ético de ciudadanos. 